\title{
Improving Science Learning Using a Combination of Concrete Inquiry Model, Numbered Head Together (NHT) Model, and Example Non-Example Model
}

\author{
Radiansyah, Leni Vera Anggraini \\ Teacher Elementary School Education Department, \\ Lambung Mangkurat University \\ Banjarmasin, Indonesia \\ radibb59@gmail.com
}

\begin{abstract}
This study was conducted by the low level of natural science learning on grade $V$ students of SDN 1 Cempaka Banjarbaru, the material for Land Formation and Soil Type Processes due to the monocular learning process and abstract material. This problem caused low student learning outcomes which were caused by teachers not using models and media learning during the learning process thus it became monotonous. The effort took using a combination of Guided Inquiry models, NHT, and Example Non-Example. This study aims to describe the activities of the teacher, students, and students learning outcomes for students in grade V SDN 1 Cempaka Banjarbaru. This study uses a qualitative approach with the type of research conducted in two cycles, which consists of 2 meetings each - the research setting of the fifth-grade students of SDN 1 Cempaka Banjarbaru with a total of 17 students in semester 2 of the academic year of 2017/2018. The result of teacher activity observation is increasing in cycle $I$ and cycle II with the outstanding category. Based on the observation, in the circle, I meeting one the students are very active and they reach $60.5 \%$ then increase in cycle I meeting 2 become $77.2 \%$. In cycle II the meeting of 1 student reached active and active $86.5 \%$ and the second cycle of meeting 2 reached $94.1 \%$. The learning outcomes in the first cycle of meeting 1 with $30 \%$ classical completeness and the first cycle of meeting 2 to $59 \%$, then increased in cycle II meeting 1 with $82.3 \%$ classical completeness followed in cycle II of meeting 2 with the classical completeness reach $94 \%$ : technical analysis, namely qualitative data analysis and quantitative data. The results of teacher and student outcomes and learning outcomes are the results of a combination of Guided Inquiry models, NHT.
\end{abstract}

Keywords - Student Learning Outcomes; Guided Inquiry; Numbered Head Together; Example Non Example

\section{INTRODUCTION}

Basic education was held to develop attitudes and abilities as well as providing experience and basic skills and needed to live in society and prepare learners who qualify to participate in secondary education. The concept of the process of land formation and soil types is the material taught in fifth-grade elementary school. The material for the process of land formation and soil types is very important to be taught in elementary schools so that students have an understanding of the process of soil formation and soil types and can know the process of soil formation that occurs in the surrounding environment. Therefore teachers are required to improve performance in active and creative learning so that they can involve all students in the learning process.

In fact, what happens in the field is based on information from fifth-grade science subject teachers of SDN 1 Cempaka Banjarbaru that in semester two students had difficulty learning in science learning materials on the material process of soil formation and soil types.

This problem can be seen from the low science learning outcomes obtained by fifth-grade students at the school. Data obtained in class V in the last two years, namely in 201 3/201 4 by six students who have reached Minimal Mastery Qualification (KKM) and 19 students have not reached KKM, with an average grade only $24 \%$. For the academic year 201 $5 / 2016$, a total of 7 students have reached KKM, and 13 students have not reached KKM, with an average of only 3 to $5 \%$ grade. The KKM value determined by the school is 70 .

Based on the results of the interview and direct observation of the teaching process of teaching carried out by the teacher, the following problems were found; in the fifth grade students of SDN 1 Cempaka Banjabaru in science learning the material process of land formation and soil types is teaching material that is abstract, and the learning process is monotonous. This happens because when observing during the learning process the teacher only explains without using models and learning media or teaching aids and only teachers who are actively involved during the learning process take place. This problem is caused by the teacher's learning not using models and media so that learning becomes monotonous so that students can only remember, record, and memorize learning material without any concrete objects that make it easier for students to understand learning so that learning is less attractive and less involved in the learning process so that students are only silent without understanding the material explained by the teacher.

Also, the weak ability of students to remember and understand the learning material explained by the teacher causes problems in learning in the material process of soil formation and soil types. With the occurrence of these problems, the impact on student learning outcomes in the last two years students experience values below KKM. Such 
conditions are certainly not expected in the teaching and learning process. If the problem is ignored without any efforts to improve it will have an impact on students' understanding of the lesson resulting in difficulties for students in the class or higher level.

Based on the problems described above, one alternative to the use of learning models to improve student activity in learning, facilitate student understanding, and create a meaningful learning atmosphere is to use a combination of Guided Inquiry models, NHT, and Example Non-Example.

The inquiry learning model is a series of learning activities that emphasize critical thinking processes and analysis to find and find answers to a question in question [1]. The Numbered Head Together learning model is a variant of group discussion. According to Slavin in reference [2], the method developed by Russ Frank is suitable for ensuring individual accountability in group discussions. The purpose of NHT is to give students the opportunity to share ideas and consider the most appropriate answers. In addition to increasing student cooperation, NHT can also be applied to all subjects and levels of students.

Example Non Example Learning Model is a learning method by preparing images, diagrams, or tables according to teaching material and competency material, serving images pasted or using LCD/OHP, with instructions from student teachers looking at the presentation, group discussion about the presentation, presentation of group results, guidance inference, evaluation, and reflection [2], [3].

Through these three models, it is expected that the fifthgrade students at SDN 1 Cempaka Banjarbaru can be fully involved in learning, remembering a set of facts from finding themselves, and facing real problems, so that learning becomes more meaningful, increases student activity and student learning outcomes.

Based on the problems in this study, it can be formulated how teacher activities, student activities and whether there is an increase in learning outcomes in the Material Formation and Soil Types Process using a combination of Guided Inquiry, NHT, and Example Non-Example models at SDN 1 Cempaka Banjarbaru?

This study aims to describe the activities of teachers, student activities and student learning outcomes in the material process of soil formation and soil types in fifth-grade students of SDN 1 Cempaka Banjarbaru. This is also supported by previous research, among the results of previous studies relevant to the results of the study as follows:

- The results of the research by reference [4] with the title "Application of Guided Inquiry Learning Strategies with the TGT cooperative model to improve the activity and student learning outcomes in the styling material and simple aircraft of class V Mambaul Ulum MI Malang." Demonstrating an increase in student learning activities from cycle I to cycle II, the percentage of learning activities increased by $15.7 \%$ which is from $58 \%$ with sufficient categories to $74.3 \%$ with good categories. While the second cycle to the third cycle, the percentage of learning activities increased by $8.3 \%$, which is from $74.3 \%$ with a good category to $82.6 \%$ with a very good category, student learning outcomes also increased sharply seen from the percentage of classical completeness, namely $66.6 \%$ in the first cycle, $76.1 \%$ in the second cycle, and $90.4 \%$ in the third cycle.

- Research result by reference [5], with the title Increasing Activity and Learning Outcomes of Science with the Application of Cooperative Learning Model Type NHT Class IV Students at SDN 1 Hajimena Academic Year 2016/2017. The NHT type of cooperative learning model can increase activity and student learning outcomes. This can be seen from the increase in student learning activities, in the first cycle, it reached $66 \%$ categorized as quite active and in the second cycle it increased to $79 \%$ in the active category. The completeness of learning outcomes in the first cycle reached $68 \%$ with an average value of 66 insufficient category, increasing to $82 \%$ at the end of cycle II with an average value of 79 categorized as good. Demonstrated an increase in learning outcomes from the first cycle reached $40 \%$ and the second cycle $86 \%$.

- Research Results by reference [6], with the title of Implementation of Model Example Non Example for Improving Science Learning Outcomes in Material Class IV Elementary School 2 Academic Mejobo Holy 2014/2015 Academic Year. The results of the study showed an increase in students' learning outcomes in the material style which was quite significant in the first cycle $(68 \%)$ and the second cycle $(93.75 \%)$. Supported by an increase in science learning activities of students in the first cycle $(62.9 \%)$ and the second cycle $(82.95 \%)$. Management of teacher learning has increased in the first cycle $(90 \%)$ to $(96.25)$ in cycle II. This proves that the implementation of the Example Non Example model can improve science learning outcomes in SD IV grade 2 material Temulus.

\section{METHOD}

This research approach using the approach Qualitative approach. The qualitative approach is to describe and to analyze the phenomena, events, social activities, attitudes, beliefs [7]. Class action research is the teacher's strategy in applying to learn by reflecting on his own experience or by comparison with other teachers. Class action research is an activity carried out to observe events in the classroom to improve the practice of learning so that it is more qualified in the process so that learning outcomes are better [8].

In class action research (CAR) there are several stages, namely planning, implementation, observation, and reflection. At the planning stage, compile a schedule of learning activities to be carried out, make a lesson plan, prepare learning media and practice equipment according to the material and prepare group worksheets, make observation sheets for observers, make an evaluation tool in the form of a written test at the end of learning. At the implementation stage, the teacher implements learning according to the step combination of the Guided Inquiry model, NHT and Example Non-Example. Observations stage in two ways, namely directly observation 
carried out by researchers of the activity of students and observation conducted by the observer on the course of study.

This classroom action research was carried out on science subjects in the matter of the process of land formation and soil types in the fifth-grade students of SDN 1 Cempaka Banjarbaru with a total of 17 students, consisting of 12 male students and five female students. This setting was chosen because it was based on data obtained from the teacher concerned showed that the fifth-grade students in semester 2 had difficulty learning in science subjects in the material of the land formation and soil types. Researchers here act as teachers, collectors, and interpreters of data.

In this study, the data collection techniques used are observations made based on teacher activity data with instruments that are the observation of teacher activities and student activity data using observation sheets of student activities and tests to measure student learning outcomes by giving test questions every time a meeting is held in the form of a written test.

This research is data analysis that is done based on teacher activities, student activities, and learning outcomes. Teacher activities and student activities were analyzed by giving scores through observed item points as many as 7 points with a score range of $1-4$ so that a minimum score of $7 \times 1=7$ and a maximum score of $7 \times 4=28$ were obtained. Range of values $=$ $28-7=21$ Interval Class $==5.25$ Rounded $=5$, from the calculation obtained it can be classified according to the criteria for teacher activity very good, good, good enough, and not good while for the activities of students individually and classically that is very active, active, quite active and less active.

The size of the presented indicators of success in this classroom action research are (1) Teacher activity; the overall learning can be accomplished at each meeting with the percentage of teachers to achieve a score of 22-28, with the criterion of "Very Good." (2) Student Activities are said to be successful if student activities in the class average can reach a score of 22-28 with the criteria of "Very Active." And classically, that is, this research is considered successful if students who are categorized as active and very active reach $\geq$ $82 \%$ - Individual Learning Outcomes, namely if a student has got a value of $\geq 75$. And Classically the Result is equal to $85 \%$ with the total number of students.

\section{RESULTS AND DISCUSSION}

Implementation of this class action was conducted in two cycles, each cycle there were two meetings, but the second cycle depending on the first cycle. If the first cycle is successful, then a second cycle does not need this class action. The first cycle of meetings one consists of scenario activities, implementing an activity, results in observation, and reflection. A sovereign, when the research still a shortage of teacher reflection to improve and enhance the Second cycle. In the second cycle of the action research first meeting consisted of scenarios, implementing activities and results of observation, if the teacher is still a lack of reflection to improve and enhance the second meeting.
TABLE I. RECAPITULATION OF TEACHER ACTIVITIES

\begin{tabular}{|l|l|l|l|}
\hline & \multicolumn{1}{|c|}{ Meeting } & \multicolumn{1}{c|}{ Score } & Criteria \\
\hline \multirow{2}{*}{ Cycle 1 } & 1 & 25 & Very good \\
\cline { 2 - 4 } & 2 & 26 & Very good \\
\hline \multirow{2}{*}{ Cycle 2 } & 1 & 27 & Very good \\
\cline { 2 - 4 } & 2 & 28 & Very good \\
\hline
\end{tabular}

In table 1 , it can be seen that there is an increase in each meeting. It can be seen from the score in the first cycle of meeting one that it gets a score of 25 with very good criteria and then at meeting two it increases again to score 26 with very good criteria. In the second cycle of meeting one the score was 27 with very good criteria then in meeting two, there was an increase again to score 28 with the criteria very good.

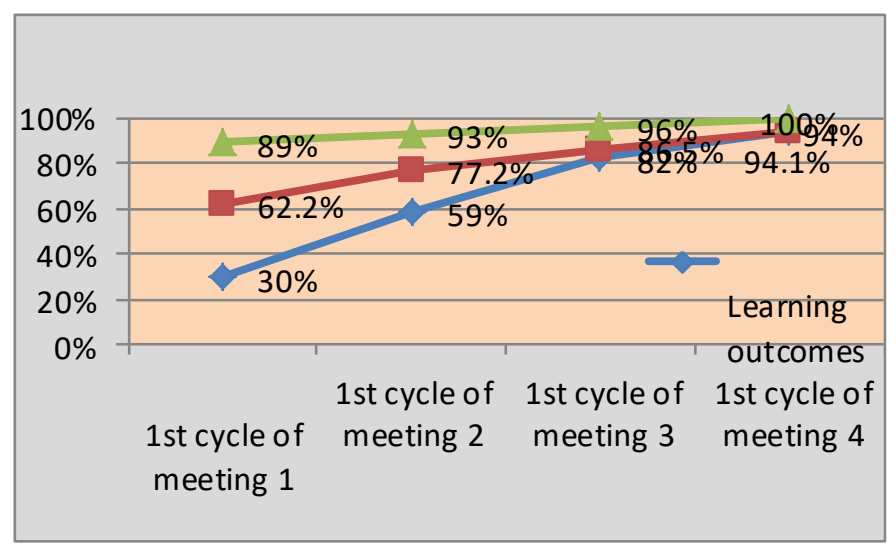

Fig. 1. Teacher Activity Improvement Trend, Activity and Student Learning Outcomes

From figure 1, it can be seen that the activity of teachers in the first cycle of meeting 1 received a percentage of $89 \%$ and meeting 2 increased to $93 \%$. In the second cycle of meeting one the percentage was $96 \%$, and at meeting two, it increased to $100 \%$. In the activities of students in the first cycle of meeting one, the percentage was $62.2 \%$ and the second meeting increased to $77.2 \%$. In the second cycle of meeting one, the percentage reached $86.5 \%$, and at meeting two, it increased again to $94 \%$. And learning outcomes in the first cycle of meeting 1 get a percentage of $30 \%$ in meeting two an increase to $59 \%$ of students complete. In the second cycle of meeting one, there was an increase in the number of students completing $82 \%$ and in meeting two it increased to $94 \%$ of students who completed.

\section{A. Teacher Activity}

The success of the teacher in carrying out the learning process is of course due to choosing a model that fits the learning material and the characteristics of elementary school students who are very fond of something new. The teacher chooses an alternative combination of guided inquiry model, NHT and Example Non-Example where this model is considered suitable to be implemented in the school that has been chosen as the research location.

Teachers play an important role in the learning process in the classroom. The teacher as a facilitator during the learning 
process, as a source of learning, the teacher becomes a leader in learning that can motivate students and be responsible for achieving the learning outcomes of students.

Learning uses a combination of Guided Inquiry models, NHT, and Example Non-Example models that are very suitable for use in science learning, especially materials for the formation of soils and soil types. Because the combined steps of the model the teacher guide students to get new information from the experiments conducted, students can understand the learning material well, the student gets concrete learning experiences and can create fun learning.

This is by the opinion of reference [8], which states that a teacher is one of the critical components in the implementation of a learning strategy class. Teachers who consider teaching only to convey material will be different from teachers who consider learning to be a process of assisting students. Each of these differences can influence both in the formulation of strategies or implementation of learning. The current educational paradigm demands a change in the learning process in the classroom. The role of the teacher is currently directed to become a facilitator who can help students in learning, not just conveying the material. The teacher must be able to involve students in learning activities optimally [9].

Inquiry model where the teacher provides an opportunity for students to participate in brainstorming with their group friends. That way the teacher's activity will increase. This is in line with Piaget's opinion [1], teachers must be able to manage student interactions so that they can develop their thinking skills systematically. The inquiry learning model also teaches the principle of interaction, where the learning process is an interaction that occurs between teachers and students, as well as students with students and students with their environment.

This strategy was first introduced in reference [10], Numbered Head Together (NHT) is a cooperative learning model that uses numbers placed on the head in order to facilitate the teacher in exploring students' activities in finding, processing, and reporting information from various sources which are finally presented in front of the class.

Example Non Example Learning Model is a learning method by preparing images, diagrams, or tables according to teaching material and competency material, serving images pasted or using LCD/OHP, with instructions from student teachers looking at the presentation, group discussion about the presentation, presentation of group results, guidance for inference, evaluation, and reflection [11].

\section{B. Student Activities}

Based on the results of observations in the first cycle and second cycle, there was an increase in student learning activities at each meeting. This is due to the accuracy of the teacher in choosing the model and applying a combination of Guided Inquiry, NHT and Example Non-Example models in class V science subjects.

Reference [12] says that learning requires learning activities. Without activity, learning cannot enable it to proceed well. Activities in teaching and learning are a series of activities which include the activeness of students in attending lessons. Among other things, asking about what is unclear, noting, listening, thinking, reading and all activities carried out to support learning achievement. Thus it can be concluded that learning activities a change in behavior in a person in the form of knowledge, understanding, and attitudes obtained through the learning process if students do learning activities then teaching activities will run effectively.

Reference [13] suggests that learning while doing activities brings more results to students because the impression obtained by students is more durable stored in the minds of students. Thus in the implementation of the learning activity is indispensable activity so that the material given student will be longer stored in the minds of students. Learning activities students not only hear or record, but many types of student activities can also be done by students at the school. In teaching and learning interactions, the teacher acts as a guide; the teacher must be able to motivate students so that the teaching and learning process can run well.

Reference $\lceil 14\rceil$ stated that inquiry strategy means a series of learning activities that involve maximally all students' abilities to search and investigate systematically, critically, logically, analytically, so that they can formulate their findings confidently. The main objectives of inquiry learning activities are (1) maximum student involvement in the learning process; (2) the direction of activities logically and systematically on learning objectives; (3) developing a belief in students about what is found in the process of inquiry.

According to reference [2], the method developed by Russ Frank is suitable for ensuring individual accountability in group discussions. NHT aims to give students the opportunity to share ideas and consider the most appropriate answers. In addition to increasing student cooperation, NHT can also be applied to all subjects and grade levels.

Model Example Non Example is a learning model that teaches students about problems around them through analysis of examples in the form of pictures, photographs, and cases that have problems. Students are directed to identify problems, find alternative solutions to problems, and determine the most effective problem-solving methods, and follow up [15].

\section{Learning outcomes}

Learning outcomes are used as a benchmark to determine the extent to which changes occur in students after learning. Thus if we conclude, someone has learned that there is a change in behavior in him [12]. According to reference [16], learning outcomes are something that is obtained from a business process after conducting learning activities that can be measured using tests to see student progress. Furthermore, reference [16] suggests that learning outcomes are measured by the average test results given and the learning outcomes test itself is a group of questions or tasks that must be answered or completed by students with the aim of measuring student learning progress.

The use of combination learning model Guided Inquiry, NHT, and Example Non-Example from the study results above have met the indicators of research success, and these results have exceeded the expected classical completeness of $\geq 85 \%$, 
and through these models can increase student activities, student learning outcomes and increased teacher activity. The implications of the success of the research conducted by the teacher are to improve student learning outcomes, be able to understand the learning material delivered and can motivate students to be able to solve a problem and complete the task given by the teacher.

Another positive thing is that students are accustomed to dealing with a problem to be solved together in group discussions because the learning process uses a combination of Guided Inquiry models, NHT, and Example Non-Example trains students in thinking skills. From the acquisition of student learning outcomes illustrated that there is an increase in each meeting. This is caused by the use of a combination of inquiry learning models, NHT and Example Non-Example that can make teacher and student activities in learning so learning outcomes increase.

\section{CONCLUSION}

Based on the analysis and discussion in implementing the learning by using a combination of Guided Inquiry, Numbered Head Together and Example Non-Example to improve learning outcomes IPA material process of soil formation and soil types fifth-grade students at SDN 1 Cempaka Banjarbaru school year 2017 / 2018 can be concluded as follows:

- Teacher activities in the soil formation process and soil types combined with the guided inquiry model, NHT, and Example Non-Example fifth grade students at SDN 1 Cempaka Banjarbaru 2017/2018 school year were implemented according to the plan in a very good category.

- Student activities in the soil formation process and soil types using a combination of Guided Inquiry models, NHT, and Example Non-Example fifth grade students of SDN 1 Cempaka Banjarbaru 2017/2018 school year with a very active category.

- Student learning outcomes in the material of soil formation and soil types using a combination of Guided
Inquiry models, NHT, and Example Non-Example fifth grade students of SDN 1 Cempaka Banjarbaru 2017/2018 school year achieved completeness both individually and classically.

\section{REFERENCES}

[1] W. Sanjaya, Learning strategies, Jakarta: Kencana Prenadia Media Group, 2006

[2] M. Huda, Teaching and learning models. Yogyakarta: Student Library, 2014.

[3] F. Indriani, "Application of guided inquiry learning strategies with cooperative TGT Model to Improve Student Activity and Learning Outcomes in Style Material and Simple Aircraft of Class V Mambaul Ulum MI Malang," 2013.

[4] Erbenezer, "Increased activity and learning outcomes of science with the application of cooperative learning model type numbered head together (NHT) class IV students at SDN 1 Hajimena academic year 2016/2017," 2017.

[5] S. Muchamat, "Implementation of model example non example for improving science learning outcomes of material in class IV elementary school 2 graduated from holy education for 2014/2015 academic year," 2015 .

[6] N. S. Sukmadinata, Educational research methods, Bandung: PT Adolescent, 2011.

[7] A. Bahri, Classroom action research. Makassar: Muhammadiyah University, 2012.

[8] A. Suriansyah, Learning strategies. Jakarta: PT Raja Grafindo Persada, 2014.

[9] Rusman, Learning models: developing teacher professionalism. Jakarta: PT Raja Grafindo Persada, 2012.

[10] A. Suprijono, Cooperative learning. Yogyakarta: Student Library, 2009.

[11] Roestiyah, Teaching and learning strategies. Jakarta: Rajawali Press, 2001.

[12] Sadiman, and S. Arief, Media education. Jakarta: Rajawali Press, 2011.

[13] S. B. Djamarah, Teaching and learning strategies. Jakarta: Rineka Cipta, 2006.

[14] W. Gulo, Teaching and learning strategies. Jakarta: Grasindo, 2002.

[15] K. Komalasari, Pembelajaran kontekstual konsep dan aplikasi. Jakarta: Rafika Aditama, 2010.

[16] Slameto, Teaching and learning process. Jakarta: Teenager Rosdakarya, 2008. 